Available online:

http://journal.imla.or.id/index.php/arabi

IMLA

Arabi : Journal of Arabic Studies, 3 (1), 2018, 23-34

DOI: http://dx.doi.org/10.24865/ajas.v3i1.62

\title{
ANALISIS KESALAHAN BERBAHASA ARAB PADA SKRIPSI MAHASISWA JURUSAN BAHASA DAN SASTRA ARAB
}

\author{
Haniah
}

Universitas Islam Negeri Alauddin Makassar, Indonesia

E-mail : haniah@uin-alauddin.ac.id

\begin{abstract}
This study aims to describe and explore: 1) Forms of hamzah writing errors, phonological errors, morphology, syntax and semantics in the students' thesis that are further evaluated and improved. 2) Factors causing language errors in students' thesis. 3) Solution to solve the problem of language error in writing thesis. This study used a qualitative content analysis approach to language errors on 3 thesis samples of academic year 2015/2016. The results showed that there was a mistake in writing the hamzah at the beginning of the word on the hamzah qath'i and hamzah washl, as well as in the middle of the word is the misplacement of alif or waw or nibrah letters under the hamzah. The solution offered was the need for Arabic learning innovation by faculty, students refer back to mu'jam in choosing the right words, improving writing skills with continuous practice, and seriousness in writing thesis.
\end{abstract}

Keywords: error analysis, imla, phonology, morphology, syntax

\section{Abstrak}

Penelitian ini bertujuan untuk mendiskripsikan dan mengeksplor: 1) Bentuk kesalahan penulisan hamzah, kesalahan fonologi, morfologi, sintaksis dan semantik pada skripsi mahasiswa selanjutnya dievaluasi dan diperbaiki. 2) Faktor penyebab kesalahan berbahasa pada skripsi mahasiswa. 3) Solusi mengatasi problema kesalahan berbahasa pada penulisan skripsi. Penelitian ini menggunakan pendekatan analisis isi kualitatif terhadap kesalahan berbahasa pada 3 sampel skripsi TA 2015/2016. Hasil penelitian menunjukkan bahwa terdapat kesalahan penulisan hamzah pada awal kata pada hamzah qath'i dan hamzah washl, begitupula pada tengah kata yaitu kesalahan penempatan huruf alif, waw, atau nibrah di bawah hamzah. Solusi yang ditawarkan adalah perlunya inovasi pembelajaran bahasa Arab oleh tenaga pengajar, mahasiswa merujuk kembali ke mu'jam dalam memilih kata yang tepat, meningkatkan keterampilan menulis dengan latihan berkesinambungan, dan keseriusan dalam menulis skripsi.

Kata Kunci: analisis Kesalahan, imla, fonologi, morfologi, sintaksis 


\section{Arabi : Journal of Arabic Studies}

\section{Pendahuluan}

Allah swt telah menganugerahkan keistimewaan terhadap bahasa Arab ketika memilihnya sebagai bahasa Alquran. Hal tersebut ditegaskan dalam Alquran QS. al-Zumar/39 : 28 (yaitu) alQuran dalam bahasa Arab tidak ada kebengkokan di dalamnya agar mereka bertaqwa.

Bahasa Arab di Indonesia mulai dipelajari sejak masuknya Islam di Indonesia yang awalnya bertujuan untuk kepentingan ibadah saja. Namun seiring dengan perkembangan pembelajaran bahasa Arab di Indonesia, bahasa Arab dipelajari tidak hanya untuk kepentingan ibadah tetapi untuk kepentingan komunikasi dengan dunia luar dan pengembangan keilmuan bahasa Arab (Izzan, 2007: 50). Saat ini bahasa Arab di Indonesia dipelajari mulai tingkatan Madrasah Ibtidaiyah sampai Perguruan Tinggi.

Universitas Islam Negeri Alauddin sebagai salah satu Perguruan Tinggi Islam yang diperhitungkan di Indonesia Timur membuka kesempatan bagi pelajar yang ingin mendalami bahasa Arab pada jurusan Bahasa dan Sastra Arab selama 8 semester dengan kewajiban tugas akhir skripsi berbahasa Arab. Skripsi adalah karya ilmiah yang diajukan mahasiswa sebagai syarat kelulusan Strata 1. Keseriusan Universitas Islam Negeri Alauddin terhadap penulisan skripsi nampak pada bobot kredit hingga 6 SKS. Hal tersebut mendorong mahasiswa untuk serius dalam penulisan skripsi. Namun sebagai pembelajar bahasa kedua tentunya mahasiswa harus mengerahkan tenaga ekstra dalam menyelesaikan tugas penulisan skripsi ini mengingat bahasa Arab bukan bahasa ibu mereka (baca: Indonesia), sehingga terkadang dalam penulisan skripsi berbahasa Arab sering mengalami kesalahan.

Kesalahan pada dasarnya adalah hal yang lumrah bagi manusia, termasuk kesalahan berbahasa. Kesalahan berbahasa adalah hal yang wajar bagi pembelajar bahasa kedua. Bagi pebelajar bahasa pertama saja sering dijumpai kesalahan baik ketika berbicara maupun menulis. Namun dalam sebuah karya ilmiah setidaknya kesalahan itu pat diminimalisir, terlebih lagi jika dipublikasikan dan dibaca khalayak. Ke depan, Perguruan Tinggi Islam termasuk UIN Alauddin akan memberlakukan aturan wajib publikasi karya ilmiah bagi mahasiswa S1, S2 dan S3 sesuai dengan aturan Dikti yang tertuang dalam surat No. 152/E/T/2012. Hal tersebut dilakukan oleh Dikti untuk meningkatkan kualitas karya ilmiah.

Skripsi sebagai sebuah karya ilmiah tentunya harus menggunakan bahasa yang baik dan benar sesuai dengan kaidah bahasa yang digunakan. Bahasa Arab sebagai bahasa yang wajib digunakan dalam penulisan skripsi mahasiswa Jurusan Bahasa dan Sastra Arab memiliki karakteristik tersendiri yang berbeda dengan bahasa Indonesia baik dari segi imla, fonologi, morfologi, sintaksis dan semantik. Hal ini menyebabkan mahasiswa kadang terjebak dalam kesalahan pemilihan kata dan begitu pula ketika merangkainya dalam kalimat bahkan dalam penulisan hamzah yang memiliki aturan tersendiri dalam kaidah imla sering terlewatkan dan tidak diindahkan dalam penulisan skripsi.

Studi analisis kesalahan berbahasa pada skripsi tidak bertujuan mencari-cari kesalahan saja tetapi kesalahan yang ada diidentifikasi dan diklasifikasikan selanjutnya ditafsirkan, dievaluasi dan diperbaiki kesalahan yang terjadi,. Olehnya itu analisis kesalahan berbahasa Arab menjadi penting dilakukan sebagai bahan acuan dan umpan balik bagi pengajar bahasa Arab agar lebih menekankan materi yang sering dijumpai kesalahannya dalam bahasa pembelajar agar mahasiswa lebih memperhatikan dan menggunakan kaidah bahasa Arab yang baik dan benar dalam menyusun skripsi sehingga kualitas karya ilmiah dapat diperhitungkan.

Penelitian ini bertujuan untuk mendeskripsikan bentuk kesalahan penulisan hamzah, bentuk kesalahan fonologi, morfologi, sintaksis dan semantik pada skripsi mahasiswa Jurusan Bahasa dan Sastra Arab UIN Alauddin Makassar selanjutnya dievaluasi dan diperbaiki. Penelitian ini juga bertujuan untuk mengeksplor penyebab kesalahan berbahasa tersebut serta menawarkan solusi mengatasi problema kesalahan berbahasa pada skripsi mahasiswa Jurusan Bahasa dan Sastra Arab UIN Alauddin Makassar. 
Secara teoritis, penelitian ini berkontribusi untuk menguji teori ilmu psikolinguistik tentang pengaruh bahasa pertama terhadap bahasa kedua yang dipelajari. Penelitian ini juga berkontribusi dalam mengembangkan teori analisis kesalahan berbahasa dalam ilmu linguistik terapan yang menyatakan penyebab kesalahan berbahasa adalah kesalahan intralingual dan kesalahan lingkungan.

Secara praktis, penelitian ini berkontribusi mengatasi problema pembelajaran bahasa Arab terkhusus pada kemahiran menulis. Penelitian ini akan membantu dalam menetapkan standard dan asas keilmuan dalam mengembangkan kurikulum pembelajaran bahasa Arab di UIN Alauddin, membantu dalam menyiapkan dan mengembangkan materi pembelajaran bahasa Arab serta membantu dalam menyiapkan teknik evaluasi yang sesuai.

Penelitian dengan pendekatan analisis kesalahan berbahasa dilakukan untuk meningkatkan تحليل الأخطاء الكتابية لدى Analysis of Writing Errors by Arabic Language Learners at Katsina University, Nigeria. Penelitian ini adalah karya disertasi yang diajukan di Pascasarjana Universitas Sains dan Teknologi Sudan tahun 2015. Penelitian ini bertujuan untuk mengetahui aspek-aspek keberhasilan dan kekurangan pembelajaran bahasa Arab terkhusus keterampilan menulis di semua tingkatan pada Jurusan Bahasa Arab Universitas Katsina dengan tujuan untuk meningkatkan keterampilan menulis pembelajar bahasa Arab sebagai bahasa kedua. Penelitian ini menggunakan metode deskriptif analitik dengan hasil penelitian : 1) Jurusan Bahasa Arab Universitas Katsina Nigeria masih membutuhkan kurikulum yang jelas dan spesifik untuk pembelajaran menulis. 2) Tidak adanya kesesuaian antara bahan ajar yang digunakan untuk pembelajaran keterampilan berbahasa pada Jurusan Bahasa Arab. 3) Jurusan Bahasa Arab masih membutuhkan dosen professional yang spesifik pada pembelajar bahasa kedua. 4) Latihan-latihan yang dipraktekkan dalam pembelajaran menulis masih sedikit dan terbatas (Harun, 2015).

الأخطاء اللغوية الكتابية لدى Sementara Hanizam Muhammad Gazali dalam tesisnya yang berjudul Writing Analysis Error of Malay Students in Using Verbal Nouns “an analysis study”. Penelitian Tesis ini diajukan pada Fakultas Ilmu Wahyu dan Humaniora Universitas Islam Internasional Malaysia pada tahun 2004. Penelitian ini bertujuan untuk mengetahui problematika kebahasaan yang dihadapi pembelajar Melayu dalam menggunakan berbagai bentuk masdar (verbal noun) ketika menulis dan mengetahui tingkat pengulangan kesalahan dengan analisis statistic. Penelitian ini menggunakan metode deskriptif analitik yang berdasar pada teori analisis kesalahan berbahasa terhadap tulisan 100 mahasiswa yang mengambil mata kuliah menulis TA 2003/2004. Hasil penelitian menunjukkan terdapat 1070 kesalahan dengan presentasi kesalahbentukan $81,32 \%$, kesalahan penanggalan $9,15 \%$, kesalahan seleksi 5,79\%, kesalahan sisipan atau selipan 3,73\%. Hasil penelitian ini juga menunjukkan bahwa sulitnya pembentukan shigah masdar dalam bahasa Arab menjadi sebab utama terjadinya kesalahan dan kesulitan dalam penulisan bahasa Arab, begitupula banyaknya masdar yang digunakan sima'i (didengar dalam ucapan orang Arab) dan bukan secara qiyasi (analogi) sehingga untuk mengetahui kebenarannya harus merujuk kepada kamus bahasa Arab untuk mengetahui kata yang digunakan oleh penutur Arab. Faktor yang lain yang menyebabkan terjadinya kesalahan adalah interferensi dari bahasa ibu ke bahasa target, kesalahan intralingual seperti ketidaktahuan tentang aturan kaidah bahasa target, tidak lengkapnya aplikasi aturan kaidah bahasa target, over generalisasi dan penyederhanaan fakta. Selain itu factor psikologis juga berperan dalam membentuk kesalahan seperti sifat ketergesa-gesaan dan sikap tidak mengindahkan (Gazali, 2004).

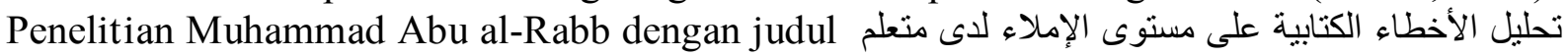
Penelitian ini dipulikasikan dalam jurnal Dirasat a-Ulum al-Insaniyah wa al-Ijtima'iyah tahun 2007. Penelitian ini bertujuan untuk menganalisis kesalahan penulisan yang menyalahi kaidah imla bagi mahasiswa bukan Arab Universitas Alul Baet. Penelitian ini mengambil sampel acak mahasiswa semester 4 yang belajar bahasa Arab dan pembelajar yang telah melewati tes kompetensi kebahasaan dan menjadi mahasiswa di berbagai jurusan di kampus 


\section{Arabi : Journal of Arabic Studies}

yang sama. Penelitian ini menggunakan metode analisis kesalahan berbahasa dalam ilmu linguistik terapan dengan tahapan identifikasi kesalahan, mendeskripsikan kemudian menafsirkan dan mengevaluasi kesalahan. Hasil penelitian ini menunjukkan bahwa pembelajar pemula yang telah melewati tes kompetensi kebahasaan kebanyakan mengalami kesalahan performansi sementara kesalahan mahasiswa semester 4 terjadi pada kesalahan kompetensi dan performansi. Penelitian ini menegaskan bahwa aturan-aturan imla berdasar pada analisis morfologi, sintaksis dan fonologi sehingga tidak adanya analisis ini menjadi penyebab terjadinya kesalahan penulisan bahasa Arab (Abu al-Rabb, 2007).

Penelitian Usman Abdullah al-Najran dan Jasem Ali Jasem dengan judul فحليل الأخطاء الكتابية Penelitian ini dipresentasikan dan dipulikasikan dalam Prosiding Seminar International Bahasa Arab ke-8 di UIN Imam Bonjol Padang tahun 2013. Penelitian ini bertujuan untuk mengetahui kesalahan pemakaian alif lam ta'rif dan huruf jar dan mengoreksi kesalahan. Hasil penelitian menunjukkan bahawa terdapat banyak kesalahan dalam penggunaan alif lam ta'rif dan huruf jar yang disebabkan oleh interferensi dari bahasa ibu ke bahasa target juga disebabkan kesalahan perkembangan diantaranya kesulitan intralingual, generalisasi, ketidaktahuan tentang aturan kaidah bahasa target, tidak lengkapnya aplikasi aturan kaidah bahasa target, hipotesis yang salah, dan kurangnya perhatian (al-Najran dan Jasem : 2013),

Beberapa kajian terdahulu yang disebutkan belum ada secara khusus membahas kesalahan berbahasa Arab pada tugas akhir mahasiswa program sarjana sehingga penilitian ini berkontribusi dalam peningkatan kualitas penulisan skripsi berbahasa Arab.

\section{Metode Penelitian}

Penelitian Analisis Kesalahan Berbahasa Arab pada Skripsi Mahasiswa Bahasa dan Sastra Arab UIN Alauddin merupakan jenis penelitian deskriptif kualitatif dengan pendekatan analisis isi terhadap kesalahan berbahasa. Karena itu, penelitian ini bertujuan untuk mengidentifikasi, mendeskripsikan, menafsirkan dan mengevaluasi kesalahan berbahasa pada skripsi mahasiswa Jurusan Bahasa dan Sastra Arab tahun akademik 2015/2016.

Data penelitian ini berupa data kualitatif yang bersumber dari Skripsi mahasiswa Jurusan Bahasa dan Sastra Arab Fakultas Adab dan Humaniora UIN Alauddin Makassar Tahun Ajaran 2015/2016 yang berjumlah 14 skripsi yang selanjutnya peneliti memilih sampel secara acak pada tiga skripsi. Selanjutnya data dikumpulkan dengan teknik mencatatat kesalahan yang ada dan wawancara dengan mahasiswa dan tenaga pengajar untuk menganalisis faktor penyebab terjadinya kesalahan.

\section{Kesalahan Berbahasa menurut Linguis Arab dan Barat}

Ulama Arab terdahulu telah mengkaji kesalahan berbahasa baik lisan maupun tulisan meskipun tidak memakai istilah kesalahan berbahasa (al-khatha' al-lugawiy) dalam karyanya. Mereka mengunakan istilah tahrif, $i$ 'wijaj al-lisan, lahn dan yang lainnya yang menunjukkan pada kesalahan. Al-Kisai, seorang ahli linguistik Arab (Wafat $189 \mathrm{H}$ ) menyusun kitab "Ma Talhana fih al- 'Awamm" kemudian menyusul al-Ashma'i (Wafat $216 \mathrm{H}$ ) menyusun kitab tentang kesalahan berbahasa yang judulnya hampir sama dengan kitab al-Kisa'i yaitu "Ma Yalhanu fih al- 'Awamm" dan Ibn al-Sikkit (W 244 H) dengan judul "Ishlah al-Manthiq”(al-'Abry, 2006 : 11).

Pada masa kontemporer, Linguis Arab melanjutkan misi para pendahulunya untuk mengingatkan adanya kesalahan berbahasa. Perhatian mereka terfokus pada bahasa tulisan, bahasa para penyair, penulis, sastrawan, wartawan, penyiar, pengajar dan pelajar. Abu al-Tsana al-Alusi adalah ulama yang pertama menyusun buku tentang perbaikan kebahasaan pada era modern dan kitabnya berjudul Kasyf al-Thurrah 'an al-Gurrah (Fahd Khalil Zayd, 2006 : 69-70). Para ulama kontemporer menjadikan majalah dan surat kabar sebagai media untuk menyebarkan gagasan mereka tentang perbaikan bahasa. Makalah-makalah mereka diantarnya dikumpulkan dalam satu 
buku seperti buku "Lugah al-Jaraid” yang disusun oleh Ibrahim al-Yazji, "Akhtha' al-Lugah al'Arabiyyah al-Sya'i'ah 'inda al-Kuttab wa al-Ida'iyyin (al-Abri, 2006 : 12).

Di Barat, Pit. S. Corder yang dikutip oleh Shini (1982 : 140) mengemukakan bahwa kesalahan berbahasa menggunakan tiga istilah yaitu lapses, error dan mistake. Lapses adalah kesalahan berbahasa akibat penutur beralih cara untuk menyatakan sesuatu sebelum seluruh tuturan selesai dinyatakan selengkapnya. Error adalah kesalahan berbahasa akibat penutur melanggar kaidah tata bahasa. Mistake adalah kesalahan berbahasa akibat penutur salah memilih kata atau ungkapan untuk situasi tertentu.

Di sisi lain, Tarigan (1988: 77) menyebutkan bahwa ada dua istilah yang saling bersinonim yaitu kesalahan (error) dan kekeliruan (mistake). Kesalahan berbahasa adalah penggunaan bahasa yang menyimpang dari kaidah bahasa yang berlaku dalam bahasa target, sedangkan kekeliruan adalah penggunaan bahasa yang menyimpang dari kaidah bahasa yang berlaku namun tidak dianggap sebagai pelanggaran berbahasa. Jadi anailisis kesalahan berbahasa difokuskan pada kesalahan berbahasa berdasarkan penyimpangan kaidah yang berlaku dalam bahasa target.

\section{Analisis Kesalahan Berbahasa}

Istilah Analisis Kesalahan Berbahasa dapat dipahami dari rangkaian tiga kata yang digunakan. Analisis berarti proses membahas dan mengurai yang bertujuan ingin mengetahui sesuatu sehingga memungkinkan dapat mengetahui inti permasalahannya. Permasalahan yang ditemukan kemudian dikupas, dikritik dan diulas lalu disimpulkan untuk dipahami (Hidayat, 2014: 162).

Analisis kesalahan berbahasa muncul pada awal tahun 70an yang merupakan bagian dari analisis konstrastif. Ada tiga langkah dalam analisis kesalahan berbahasa (Thu'aimah, 1989: 54) yaitu :

a. Mengidentifikasi kesalahan; hal ini dimaksudkan untuk menentukan letak penyimpangan aturan bahasa yang dilanggar oleh penutur bahasa kedua

b. Mendeskripsikan kesalahan; hal ini dimaksudkan untuk menjelaskan aspek penyimpangan yang terjadi seperti penanggalan, seleksi, salah urut dan penempatan.

c. Menafsirkan kesalahan; yaitu menjelaskan factor-faktor yang menyebabkan terjadinya kesalahan berbahasa kemudian mengoreksi kesalahan dan menyebutkan yang benar.

Adapun tujuan analisis kesalahan berbahasa menurut Corder memiliki dua tujuan yaitu tujuan teoritis dan tujuan praktis. Senada dengan Corder, Tarigan (1988 : 77) mengatakan bahwa tujuan dari analisis kesalahan berbahasa itu bersifat aplikatif dan teorits. Aplikatif mengurangi dan memperbaiki kesalahan berbahasa siswa. Teoritis mengharapkan pemerolehan bahasa siswa yang pada gilirannya dapat memberikan pemahana ke arah pemerolehan bahasa secara umum.

Terlepas dari itu analisis kesalahan berbahasa yang dilakukan oleh seorang guru atau peneliti dapat membantu mengidentifikasi kesalahan dan penyebabnya sehingga dapat merubah metode atau teknik mengajar yang digunakan dan menjadi acuan dalam merencanakan pembelajaran bahasa.

\section{Bentuk Kesalahan Berbahasa}

Kesalahan yang terjadi pada pembelajara bahasa kedua dapat dikategorikan sebagai kesalahan interlingual dan kesalahan intralingual yang dapat berbentuk kesalahan penulisan ejaan, kesalahan sintaksis, kesalahan morfologis dan kesalahan semantik.

Kesalahan yang tejadi pada pembelajar bahasa kedua ada yang dapat mempengaruhi komunikasi dan ada pula yang tidak berpengaruh pada proses komunikasi. Hendricson mengistilahkan dua bentuk kesalahan yaitu kesalahan global dan kesalahan local.

Marina Burt yang dikutip oleh Shini (1982 : 167-169) mengungkapkan bahwa kesalahan global adalah penyimpangan struktur kalimat secara keseluruhan yang berpotensi menghambat komunikasi dan tidak sampainya pesan kepada komunikan. Kesalahan global juga merupakan 


\section{Arabi : Journal of Arabic Studies}

kesalahan struktur bahasa kedua yang mempengaruhi makna atau maksud kalimat secara keseluruhan sehingga mempengaruhi aspek komunikasi.

Sedangkan kesalahan lokal atau dikenal dengan kesalahan linguistik merupakan penyimpangan struktur kebahasaan yang tampak aneh dan janggal, tetapi tidak menyebabkan penutur bahasa sasaran tidak memahami makna yang terkandung dalam struktur suatu kalimat.

Berdasarkan dari uraian tersebut bentuk kesalahan berbahasa dapat berupa kesalahan interlingual atau kesalahan developmental, kesalahan intralingual, kesalahan global dan kesalahan local.

Kesalahan interlingual terjadi karena pengaruh bahasa ibu dalam mentransfer bahasa target seperti transfer dari bahasa bugis ke bahasa Arab. Lidah orang bugis hanya terbisa menyebut hurus 's' sehingga ketika membaca ayat صر اط الذين أنعت عليهم kata الذين dibaca allasina.

Kesalahan intralingual atau kesalahan yang terjadi dalam bahasa target. Jadi sumber kesalahan pembelajar bahasa Arab dapat dilihat pada taksonomi linguistik bahasa Arab itu sendiri baik dalam tatanan bunyi/fonetik, kaidah imla, tatanan sintaksis, morfologis, dan semantic.

Selain bentuk kesalahan intralingual tersebut, berikut beberapa contoh kesalahan intralingual lainnya yang meliputi :

a. Penanggalan dan penambahan (النقص والزيادة) seperti جامعة اندونيسيا مشهور في اندونيسيا kata مشهور terjadi penanggalan huruf : karena kedudukannya sebagai sifat yang harus mengikuti yang disifati yaitu kata جامعة

b. Persesuaian ( مطابقة ) seperti الطلاب يدرس اللغة العربية في الفصل kata , يدرس yang berkedudukan

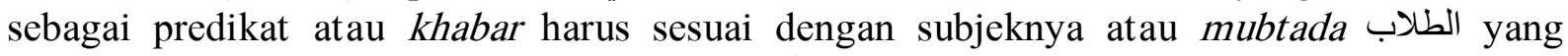
bentuknya jamak maka seharusnya الطلاب يدرسون .

c. Kesalahan tanda i'rab pada akhir kata seperti انتريت كتابان في المكتبة. Dalam bahasa Arab kata yang berkedudukan sebagai objek tanda i'rab-nya manshub dan setiap kata yang berbentuk dual tanda i'rab-nya adalah ' ي 'jadi seharusnya kalimat yang benar adalah: اشتريت كتابين في المئ .

d. Ketepatan pemilihan diksi seperti ذهبت إلى الجامعة مشيا على الرجل (saya ke kampus dengan

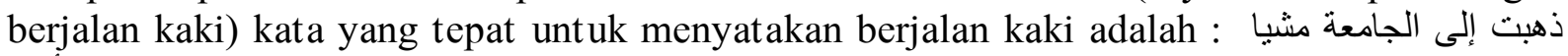
على الأقدام

\section{Faktor Penyebab Kesalahan Berbahasa}

Secara umum ada dua faktor yang menyebabkan kesalahan berbahasa yaitu :

a. Faktor Interferensi

b. Faktor Developmental

Secara khusus faktor yang menyebabkan kesalahan penulisan ejaan diantaranya:

a. Faktor Kelemahan Anggota Tubuh

b. Faktor Pedagogik

c. Faktor Penulisan Bahasa Arab

1) Adanya ketidaksesuaian antara penulisan huruf hijaiyyah dan bunyinya yang merupakan bunyi harakat yang menyertainya.

2) Kesamaan bentuk penulisan pada beberapa kata tetapi memiliki arti yang berbeda

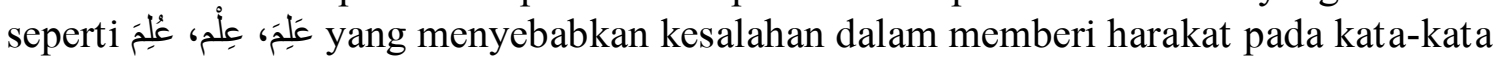
tersebut.

3) Keterkaitan kaidah imla dengan kaidah nahwu dan sharaf yang menyebabkan kesulitan dalam penulisan.

4) Bercabangnya kaidah penulisan imla dan banyaknya perbedaan dan pengecualian pada kaidah tersebut. Seperti kaidah penulisan hamzah pada pertengahan kata penulisannya berbeda seiring dengan perbedaan harakat hamzah atau harakat yang mendahuluinya secara langsung. 


\section{Hasil Penelitian dan Pembahasan}

1. Bentuk kesalahan penulisan hamzah pada skripsi mahasiswa Jurusan Bahasa dan Sastra Arab UIN Alauddin Makassar dan perbaikannya

a. Kesalahan Penulisan Hamzah di awal kata.

Berdasarkan penelusuran pada skripsi mahasiswa Jurusan BSA UIN Alauddin maka peneliti menemukan beberapa kesalahan penulisan hamzah qath'i dan hamzah washl yang tidak menjadi perhatian mahasiswa dalam penulisan skripsi sehingga terjadi penanggalan bagian atas huruf 'ain pada hamzah qath'i dan dan penambahan bagian atas huruf 'ain pada hamzah washl.

Berikut bentuk kesalahan penulisan hamzah yang terletak di awal kata :

1) Penanggalan hamzah di awal kata bentuk jamak

Ada beberapa bentuk jamak taksir yang diawali dengan huruf hamzah setimbang dengan أفعال . Dalam hal ini ada beberapa kata yang ditemukan tidak diberi tanda hamzah di atas alif sehingga

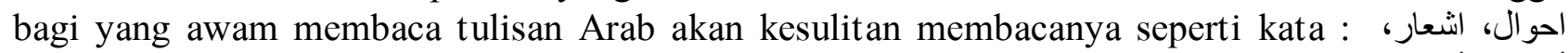

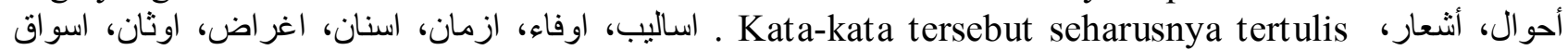

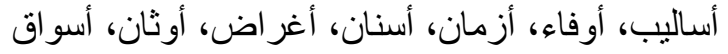

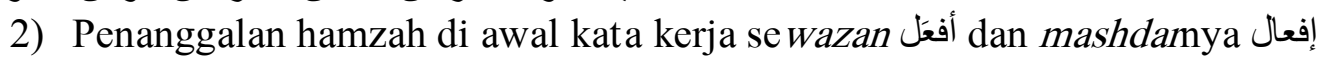

Kata kerja dan mashdar yang terdiri dari tiga huruf yang mendapat tambahan hamzah perlu diberi tanda hamzah di atas alif untuk kata kerja dan di bawah alif untuk mashdar. Hal ini untuk membedakan antara hamzah qath'i dan hamzah washl. Dalam skripsi mahasiswa ditemukan

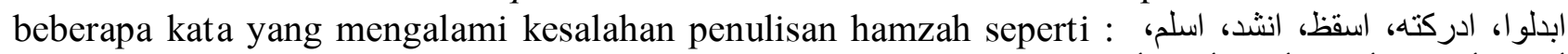

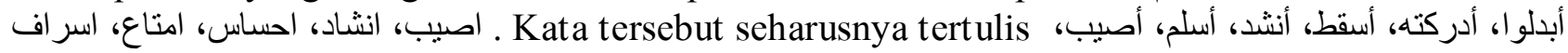

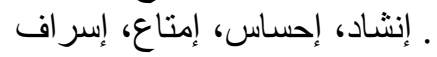

3) Penanggalan hamzah di awal kata bentuk isim tafdhil

Isim tafdhil atau kata yang menunjukkan superlative dalam bahasa Arab dibentuk setimbang dengan Penulisan hamzah di atas alif perlu dilakukan untuk memudahkan untuk indetifikasi kata. Kesalahan tersebut misalanya Nampak pada kata أشهر هم، اكبر ، اكثر . Kata tersebut seharusnya tertulis أشهر هم، أكبر، أكثر أ.

4) Penanggalan hamzah pada awal huruf

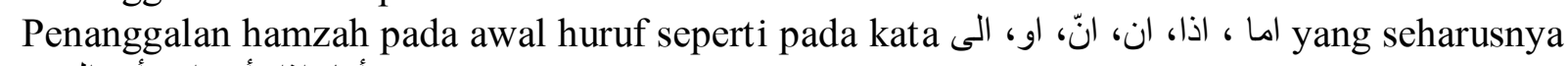

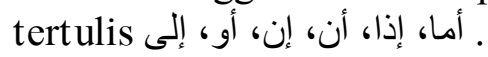

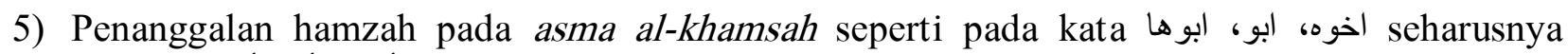
أخوه، أبو، أبوها tertulis

6) Penanggalan hamzah pada isim jamid yang diawali dengan hamzah qath'i. Seperti pada kata أحمد، إبر اهيم، أهل، أسرة، أدبة seharusnya tertulis احمد، ابراهيم، اهل، اسرة، ادبة

7) Penambahan hamzah pada kata kerja atau mashdaryang diawali hamzah washl.

Kata kerja yang mendapat tambahan dua huruf alif dan ta menjadi فتعل atau alif dan nun menjadi انفعل ataukah tiga huruf alif, sin, dan ta menjadi استفعل kesemuanya diawali dengan hamzah washl yang ketika didahului huruf waw atau fa maka hamzahnya tidak terbaca sehingga ditulis dengan huruf alif saja tanpa ada bagian atas huruf 'ain di atas alif atau di bawahnya. Seperti yang ditemukan dalam skripsi, alif ditulis dengan menambahkan huruf atas 'ain di bawah alif pada kata اعتذار، انفعالات، اعتبار، الاستعارة Kata-kata tersebut seharusnya tertulis إعنذار، إنفعالات، إعنبار ، الإستعارة.

8) Penambahan hamzah pada kata benda yang diawali hamzah washl

Diantara kata benda yang diawali hamzah washl adalah kata اسم (ism) sehingga penulisan hamzah hanya dengan huruf alif saja tanpa meletakkan bagian atas huruf 'ain di bawah huruf alif. Dalam skripsi mahasiswa masih ditemukan penambahan bagian atas huruf 'ain di bawah huruf alif seperti dalam kata و و وإسمد seharusnya kata tersebut ditulis و

b. Kesalahan Penulisan Hamzah di Tengah

Kaidah penulisan hamzah di tengah tergantung pada bunyi harakatnya atau harakat sebelumnya kemudian ditulis di atas huruf yang paling kuat diantara dua harakat. Harakat yang paling kuat secara berurutan adalah kasrah, dhammah, fathah dan sukun. Kasrah selaras dengan ya, 


\section{Arabi : Journal of Arabic Studies}

dhammah selaras dengan waw, fathah selaras dengan alif dan sukun tidak selaras dengan satu huruf pun.

Sebagai contoh kata يَنَأَل hamzah ditulis di atas huruf alif karena fathah lebih kuat dari pada sukun. Pada kata سُوَال hamzah ditulis diatas huruf waw karena dhammah lebih kuat dari fathah. Pada kata سُئِل hamzah ditulis di atas nibrah (ya yang tidak pakai titik) karena kasrah lebih kuat dibanding dhammah.

Dalam skripsi mahasiswa masih ditemukan beberapa kesalahan dalam penulisan hamzah di tengah kata seperti pada kata : مُأثر ، بمبدإه، جزئ seharusnya tertulis مؤثر، بمبئه، جزئئ .

2. Bentuk kesalahan fonologi, morfologi, sintaksis dan semantik pada skripsi mahasiswa Jurusan Bahasa dan Sastra Arab UIN Alauddin Makassar dan perbaikannya.

a. Kesalahan Fonologi

1) Kesalahan merefleksikan bunyi huruf seperti huruf shad diganti dengan sin pada kata ditulis مسطفى, atau huruf dhad ditulis dengan huruf dal pada kata أغرادهم ditulis أغر اضهم أ

2) Penanggalan dan penambahan bunyi panjang

Bunyi panjang terkadang dibunyikan pendek atau sebaliknya bunyi pendek dibunyikan panjang. Hal tersebut berimplikasi pada penulisan sehingga menyebabkan kesalahan. Kata-kata yang terjadi kesalahan penulisan yang ditemukan dalam skripsi seperti : إحد، دوكتور، الثنوي، ذا القعدة، إحدى، دكتور، الثانوي، ذي القعدة kata tersebut seharusnya tertulis خصة

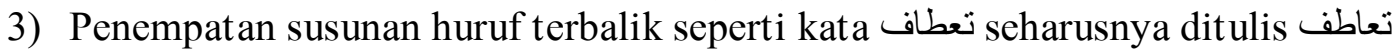

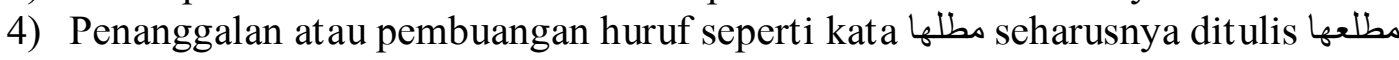

b. Kesalahan Morfologi

1) Kesalahan bentuk sigah kata kerja

Dalam skripsi mahasiswa masih dijumpai kesalahan penempatan kata kerja bentuk madhi pada posisi kata kerja bentuk mudhari'. Seperti pada kata لآثر ketika lam ta'lil masuk pada kata kerja bentuk madhi sedangkan dalam aturan tata bahasa Arab seharusnya menyertai kata kerja

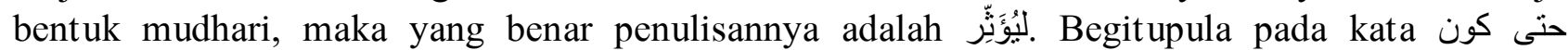
seharusnya ditulis dalam bentuk mudhari حتى يكون .

2) Kesalahan bentuk sigah jamak

Dalam morfologi bahasa Arab pembentukan kata tunggal menjadi jamak dapat dibentuk dengan salah satu dari tiga bentuk jenis jamak yaitu jamak muannats yang ditambahkan alif dan ta, jamak mudzakkar yang ditambahkan waw dan nun atau ya dan nun dan jamak taksir yang tidak tertentu formatnya yang terkadang mengalami penambahan huruf ataupun pengurangan huruf. Hal tersebut dapat mengakibatkan kesulitan pada pembelajar bahasa Arab sebagai bahasa kedua karena banyaknya bentuk jamak taksir. Sehingga seorang pembelajar bahasa Arab sebagai bahasa kedua harus memiliki banyak kosa kata yang disertai pengetahuan tentang bentuk jamaknya dengan banyak pengalaman dari membaca teks-teks berbahasa Arab.

Di antara kesalahan format membentuk kata jamak yaitu pada kata عصر yang ditulis dalam bentuk jamak أعصر yang seharusnya dibentuk jamak dengan sigah فعول sehingga yang benar adalah Hal tersebut terjadi bisa disebabkan karena generalisasi berlebih ketika ingin menyamakan dengan kata شهر yang dibentuk jamak menjadi أشهر .

3) Kesalahan format sigah nasab.

Nasab atau nisbah dalam kajian morfologi bahasa Arab adalah menambahkan ya ber-tasydid di akhir kata yang dikasrah sebelumnya untuk menunjukkan nisbah sesuatu kepada yang lain. Ketika suatu kata ditambahkan dengan ya nisbah maka terjadilah perubahan lafaz, makna dan hukumnya. Perubahan lafaz yang terjadi tergantung kata dasarnya dan mengikuti beberapa aturan dalam pembentukan sigah nasab seperti kata yang berakhiran ta marbuthah maka ketika dibentuk menjadi sigah nasab, ta tersebut harus dibuang seperti kata مكة - مكي .

Di antara kesalahan format sigah nasab yang ditemukan dalam skripsi mahasiswa adalah pada frase فعيلة Dalam tata bahasa Arab kata yang setimbang العصيبة القبيلة ketika dibentuk 
menjadi sigah nasab maka aturannya huruf ta dan ya harus dibuang dan huruf kedua berubah harakatnya dari kasrah menjadi fathah. Maka yang benar penulisannya adalah العصبية القََليّلة .

4) Kesalahan format sigah mashdar

Bentuk mashdar dalam bahasa Arab ada yang sima'i dan ada yang qiyasi. Jika asal kata mashdar terdiri dari tiga huruf maka bentuk mashdarnya pada umumnya bersifat sima'i, yang menyebabkan pembelajar bahasa Arab sebagai bahasa kedua mengalami kesulitan jika kurang perbendaharaan kosa kata dari pengalaman membaca teks-teks bahasa Arab. Adapun yang asal katanya terdiri dari empat huruf atau lebih pada umumnya bentuk mashdarnya bersifat qiyasi sehingga dengan pengetahuan yang memadai tentang bentuk mashdar dari bentuk-bentuk kata kerja yang terdiri dari empat huruf, lima huruf atau enam huruf dapat memudahkan pembelajar bahasa Arab sebagai bahasa kedua untuk membentuknya. Namun yang sering menyebabkan kesalahan jika salah menafsirkan bentuk dasar kata kerjanya.

Dalam penelusuran peneliti terhadap karya tulis skripsi mahasiswa masih ditemukan bentuk mashdar yang seharusnya kata dasarnya terdiri dari empat huruf namun disalahtafsirkan menjadi mashdar dari asal kata tiga huruf. Seperti kata كون yang seharusnya adalah تكوين karena berasal dari empat huruf كوّن yang berarti membentuk atau menjadikan.

5) Pertukaran tempat sigah sifah musyabbahah di tempat sigah mashdar.

كثيرة المراجع Siantara kesalahan penggunaan sigah sifah musyabbahah ditemukan pada frase yang seharusnya di tempat ini menggunakan sigah mashdar yaitu كثرة المراجع.

c. Kesalahan Sintaksis

1) Penambahan alif lam pada kata yang sandar

Idhafah dalam bahasa Arab adalah istilah yang digunakan ketika menyandarkan suatu kata kepada kata yang lain yang pada umumnya berarti kepemilikan. Dalam aturan tata bahasa Arab kata yang sandar tidak boleh disertai dengan alif lam atau tanwin dan membuang nun pada kata bentuk dual maupun jamak.

Namun dalam penelusuran peneliti terhadap skripsi mahasiswa kesalahan pada penulisan kata-kata yang sandar banyak dijumpai yaitu dengan menambahkan alif lam pada kata tersebut. Di antara kata-kata tersebut adalah: الاستيفاء بعض الثروط، الثعر اء العصر الجاهلي، جميع الأصدقائي، أقدم الآثر seharusnya frase tersebut ditulis dengan tidak menyertakan alif lam pada kata yang sandar

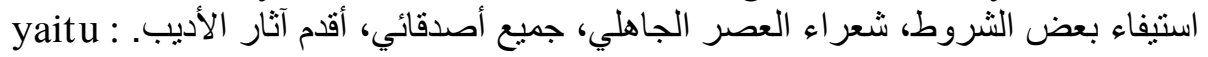

2) Ketidak sesuaian dalam sifah mausuf

Dalam tata bahasa Arab penggunaan sifah harus disesuaikan dengan yang disifati (maushuf) pada berbagai aspek meliputi aspek ta'rif dan tankir, tadzkir dan ta'nits, i'rab, serta kuantitas bilangannya dari segi mufrad mutsanna dan jamak.

Berdasarkan penelusuran peneliti pada skripsi mahasiswa ditemukan beberapa ketidak sesuaian antar shifah dan maushufnya pada aspek ta'rif dan tankir, tadzkir dan ta'nits serta i'rab. Berikut di antara frase yang mengalami kesalahan karena ketidaksesuaian antar sifah dan

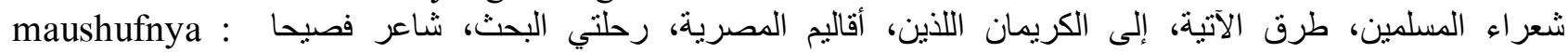
الثعر اء المسلمون، الطرق الآتية، الكريمين اللذين، : الأقاليم المصرية، رحلتي البحثية، شاعر ا فصيحا.

3) Kesalahan penyesuaian kata kerja dengan pelakunya

Dalam kaidah bahasa Arab antara kata kerja dan pelaku harus disesuaikan berdasarkan tadzkir dan ta'nits, mufrad, mutsanna, dan jamak serta posisi pelaku sebagai orang ketiga, kedua atau pertama dalam pembicaraan. Diantara kesalah tersebut ditemukan dalam skripsi mahasiswa

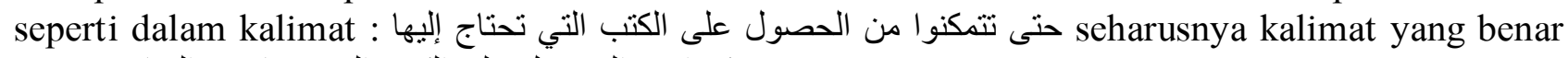
adalah : حتى تتمكنو ا من الحصول على الكتب التي يحتاجون إليهاج :

4) Ketidaksesuaian kata tunjuk dengan kata yang ditunjuk

Kaidah penulisan kata tunjuk dalam bahasa Arab adalah menyesuaikan antara kata tunjuk dan sesuatu yang ditunjuk berdasarkan jenis kata, apakah muannats atau muzakkar, mufrad, 


\section{Arabi : Journal of Arabic Studies}

mutsanna atau jamak. Kesalahan tersebut dapat dilihat misalnya pada frase هذا الرسالة karena kata yang ditunjuk berbentuk muannats mufrad maka seharusnya tertulis هذه الرسالة.

5) Ketidaksempurnaan kalimat yang menggunakan إن

Penggunaan kata إن dalam bahasa Arab membutuhkan isim dan khabar untuk menjadikan sebuah kalimat yang sempurna. Namun mahasiswa dalam skripsinya lalai akan hal tersebut seperti

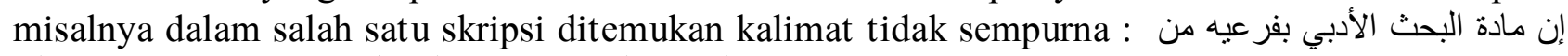
Kalimat tersebut masih memerlukan khabar untuk menyempurnakannya seperti frase موضو من شنائق اللبحث الأدبرن

6) Kesalahan i'rab

Salah satu keistimewaan bahasa Arab yang tidak ada pada bahasa lain adalah sebagai bahasa i'rab yaitu adanya kata-kata yang mengalami perubahan harakat atau huruf pada akhir kata berdasarkan posisinya dalam kalimat. Di antara kesalahan yang ditemukan dalam skripsi adalah penulisan kata ذو ذو yang posisinya sebagai mudhaf ilaih seharusnya berubah menjadi ذو ذو

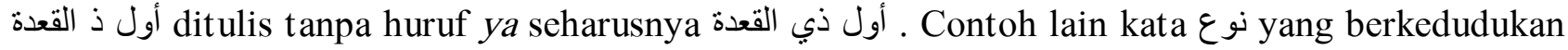
sebagai objek pada kalimat تستخدم هذه الرسالة نوع من البحث المكتبي

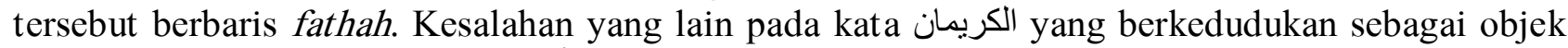
dari kata kerja yang terbuang أخص pada kalimat وخاصة .... الكريمان اللذين seharusnya alif pada kata وخاصة ... الكريمين اللذين tersebut yang menunjukkan dual berubah menjadi ya

d. Kesalahan Semantik

1) Ketidak tepatan pemilihan huruf jar setelah kata kerja

Pemilihan huruf jar yang disandingkan dengan kata kerja sangat berpengaruh pada pemaknaan seperti antara huruf في dang terletak setelah kata kerja رغب عuruf pertama menunjukkan makna tidak senang sedangkan huruf kedua menunjukkan makna senang. Diantara الحصول على seharusnya الحصول مواد kesalahan yang terdapat dalam skripsi mahasiswa seperti frase

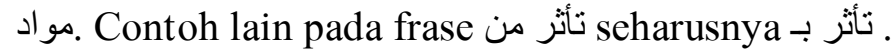

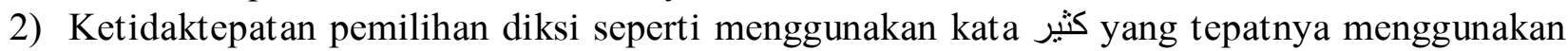
kata

\section{Faktor-Faktor penyebab kesalahan berbahasa pada skripsi mahasiswa Jurusan Bahasa dan Sastra Arab UIN Alauddin Makassar.}

Berdasarkan data wawancara dengan mahasiswa dan tenaga pengajar bahasa Arab pada Fakultas Adab dan Humunioran UIN Alauddin ditemukan beberapa faktor penyebab kesalahan berbahasa pada skripsi mahasiswa diantaranya : pertama : interferensi bahasa ibu, kedua : ketidakmampuan mahasiswa menaati kaidah bahasa Arab, ketiga : kesalahan penafsiran terhadap kaidah yang diperoleh, keempat : tidak ada pedoman penulisan.

\section{Solusi mengatasi kesalahan berbahasa pada skripsi mahasiswa Jurusan Bahasa dan Sastra Arab UIN Alauddin Makassar.}

Diantara solusi yang ditawarkan untuk mengatasi kesalahan berbahasa pada skripsi mahasiswa Jurusan Bahasa dan Sastra Arab adalah :

a. Inovasi pembelajaran qawāid imla, ashwat, nahwu, sharf dan dilalah

b. Merujuk ke mu'jam bahasa Arab dalam memastikan ketepatan pemilihan kata.

c. Menambah wawasan tentang bahasa Arab dan meningkatkan keterampilan berbahasa.

d. Pembelajaran qawāid imla, nahwu dan sharaf lebih menekankan pada latihan fungsional bukan hanya berkut at pada teori tanpa praktek.

e. Keseriusan mahasiswa dalam menulis skripsi dan tidak mengandalkan pembimbing dan penguji sebagai editor. 


\section{Simpulan}

Karya ilmiah di Perguruan Tinggi harus mendapat perhatian yang serius dari berbagai pihak, terutama peneliti dalam menulis laporan penelitian hendaknya meminimalisir kesalahan-kesalahan dengan lebih teliti dalam menulis agar terhindar dari kesalahan baik yang menyalahi kaidah imla terutama dalam penulisan hamzah serta kaidah nahwu dan saraf. Kesalahan penulisan hamzah pada skripsi mahasiswa Jurusan Bahasa dan Sastra Arab terdapat pada awal dan pertengahan kata. Kesalahan Fonologi terdapat pada kesalahan refleksi bunyi huruf, penanggalan dan penambahan bunyi panjang dan penempatan susunan huruf yang terbalik. Kesalahan Morfologi terdapat pada kesalahan bentuk sigah kata kerja, kesalahan bentuk sigah jamak, kesalahan sigah nasab, kesalahan format sigah mashdar dan penggunaan sigah sifah musyabbahah di tempat sigah mashdar. Kesalahan Sintaksis terdapat pada kesalahan penggunaan idhafah, kesalahan dalam merangkai sifah mausuf, kesalahan penyesuaian kata ganti, kesalahan dalam kalimat إن, kesalahan tanda i'rab dan penanggalan alif lam ta'rif. Kesalahan Semantik terdapat pada kesalahan penempatan huruf jar setelah kata kerja dan ketidaktepatan pemilihan diksi.

Adapun Faktor-Faktor penyebab kesalahan berbahasa pada skripsi mahasiswa Jurusan Bahasa dan Sastra Arab UIN Alauddin Makassar adalah interferensi bahasa ibu, ketidakmampuan menaati kaidah bahasa Arab, kesalahan penafsiran terhadap kaidah yang diperoleh, serta tidak ada pedoman penulisan yang berbahasa Arab.

Solusi mengatasi kesalahan berbahasa pada skripsi mahasiswa Jurusan Bahasa dan Sastra Arab UIN Alauddin Makassar melalui ; pertama: inovasi pembelajaran qawaid imla, aswat, nahwu, sharf dan dilalah, kedua : Mahasiswa merujuk ke mu'jam bahasa Arab dalam memastikan ketepatan pemilihan kata, ketiga: Menambah wawasan tentang bahasa Arab dan meningkatkan keterampilan berbahasa, ketiga: Pembelajaran qawaid imla, nahwu dan sharaf lebih menekankan pada latihan fungsional bukan hanya berkutat pada teori tanpa praktek, keempat; Keseriusan mahasiswa dalam menulis skripsi dan tidak mengandalkan pembimbing dan penguji sebagai editor.

Implikasi penelitian ini adanya desain pembelajaran bahasa Arab yang inovatif sehingga pembelajaran bahasa Arab lebih aplikatif pada kemahiran berbahasa. Perlunya disusun pedoman penulisan karya ilmiah yang berbahasa Arab. Materi pembelajaran disusun berdasarkan kesulitan yang dialami mahasiswa dalam pembelajaran imla, nahwu, dan sharf. Mahasiswa memacu diri untuk meningkatkan kompetensi kemahiran berbahasa terkhusus menulis dan tidak mengandalkan pembimbing dan penguji sebagai editor.[]

\section{Daftar Rujukan}

al-`Abri, Khalid Hilal Nasir. 2006. Akhtha’ Lugawiyyah Sya'i’ah. Cet. I; Oman : Dar al-Jael.

Abu al-Rabb, Muhammad. 2007. "Tahlil al-Akhtha' al-Kitabiyyah 'Ala Mustawa al-Imla Ladae Muta'allimi al-Lugah al-"Arabiyyah li Ghair al-Nathiqina biha” Jurnal Dirasat a-Ulum alInsaniyah wa al-Ijtima'iyah, Vol. 34, No. 2, hal 1-14.

Gazali, Hanizam Muhammad. 2004. “al-Akhtha' al-Lugawiyyah al-Kitabiyyah Ladae al-Thullab al-Malayuwiyyin fi Istikhdam al-Mashdar; Dirasah Tahliliyah" Tesis tidak diterbitkan. Malaysia : Fakultas Ilmu Wahyu dan Humaniora Universitas Islam Internasional Malaysia..

Harun, Hajar Khamis. 2015. "Tahlil al-Akhtha al-Kitabiyah Ladae Thullab Qism al-Lugah al'Arabiyah bi Jami'ah Katsina Nigeria" Disertasi tidak Diterbitkan. Khortoum : Pascasarjana Universitas Sains dan Teknologi Sudan.

Hidayat, Nandang Sarip. 2014. "Analisis Kesalahan dan Konstrastif dalam Pembelajaran Bahasa Arab. Kutubkhanah, Vol. 17, No. 2, Juli-Desember, 160-174.

Izzan, Ahmad. 2007. Metodologi Pembelajaran Bahasa Arab. Cet. II; Bandung: Humaniora.

al-Najran. Usman Abdullah dan Jasem Ali Jasem. 2013. "Tahlil al-Akhtha' al-Kitabiyah fi Ba'dh al-Zawahir al-Nahwiyyah fi Kitabat al-Thullab Ghair al-Nathiqina al-‘Arabiyyah” Prosiding 
Arabi : Journal of Arabic Studies

Seminar International Bahasa Arab Khithab al-Tajdid fi al-Dirasat al- 'Arabiyyah Baina alNazariyah wa al-Tathbiq. Padang: UIN Imam Bonjol Padang, hal. 66-96.

Shini, Ismail dan Ishak Muhammad al-Amin. 1982. Al-Taqabul al-Lugawi wa Tahlil al-Akhta'. Riyad : Universitas Malik Sa’ud.

Tarigan, Henri Guntur. 1988. Pengajaran Analisis Kesalahan Berbahasa. Bandung: Penerbit Angkasa.

Thu'aimah, Rusydi Ahmad. 1989. Ta'lim al-'Arabiyyah li Ghair al-Nathiqina biha; Manahijuh wa Asalibuh. Rabat : Esesco.

Zayd, Fahd Khalil. 2006. Al-Akhtha' al-Sya'i'ah al-Nahwiyyah wa al-Sharfiyyah wa alImla'iyyah. Jordan : Dar al-Yazori. 